\title{
Decolonising schools in South Africa: The impossible dream?
}

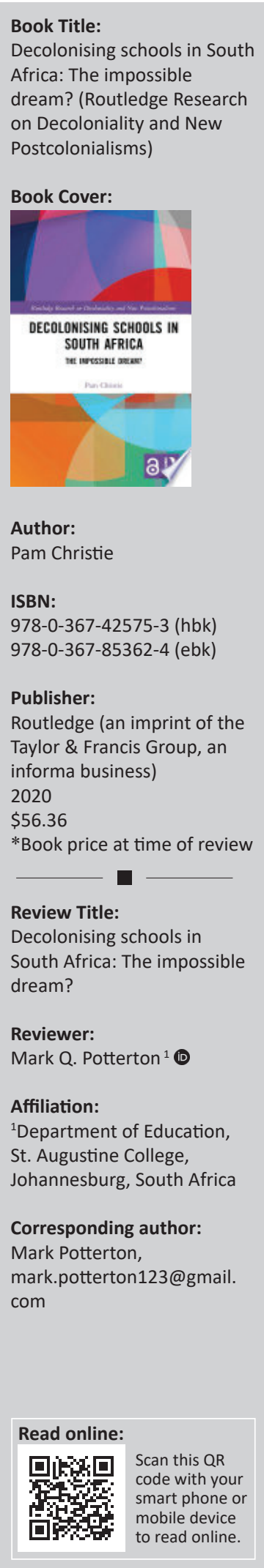

Pam Christie has published pioneering work on South African education for the past 40 years. In the Catholic school context, Christie's work on the open school's movement was groundbreaking and provided an account of the experience of racial mixing, which was unique at the time. One of the things she revealed was that admitting black pupils to 'white' schools did not necessarily bring a greater understanding of racial oppression and that many still denied the existence of racial differences within the schools.

Schooling in the semi-desert Karoo town of Carnarvon provides the backdrop for Decolonising Schools in South Africa, a new book by this veteran scholar. From the vantage point of this marginal town, Christie throws light on the changes that have ensued in this place and the schools therefrom colonial times to the period after apartheid. After a thorough ground research, Christie describes a 'decolonial moment' for South African schools.

'In magnifying one place on a very large canvas of schools', Christie writes:

$[T]$ he intention is to provide insights into the multiple ways in which inequalities in schooling take shape, endure, and shift - insights that are not easily identified by the broad histories and policy analyses of education alongside which this book is written. (p. 3)

In the first chapter, Christie mainly uses historical sources (secondary and primary) to show the impact of colonial expansion into the semi-arid, sparsely populated land in the 1800 s and to show patterns of possession and dispossession.

This thorough study of education and schooling in the town of Carnarvon, both inside and outside of the classroom over this critical time in South Africa's history, reflects Christie's 'longstanding commitment to working for social justice in education'. She explores the story of colonial education in a specific context in which the attempts to decolonise education in this town have failed.

\section{Christie observes that:}

Schools, are emblems of modernity, and though they are flawed institutions, their social mandate is important to provide systematic teaching and learning for young people in ways that prepare them to contribute to a shared world and, hopefully, change it for the better. (p. 2)

Drawing on her visits to hundreds of schools in South Africa and Australia over many years, Christie has been fascinated by the differences and the similarities between schools. She expressed:

There is a 'sameness' to schools, such that it would be hard for me to come upon a school and not recognise it for what it is - even if there are no buildings, or if classes are conducted under trees. At the same time, despite their sameness, schools are very different places, and each has its own distinctive vitality or tonality. (p. 2)

In her work on schools achieving good results in poorer contexts, she showed how their daily rhythms and expectations were different from that of the other schools. Catholic schools in these contexts had higher expectations both in behaviour and in achievement for both their teachers and pupils.

In this study, Christie observes that the differences between schools reveal the profound inequalities present in this broader society, and that there is a general agreement amongst

How to cite this book review: Potterton, M.Q., 2021, 'Decolonising schools in South Africa: The impossible dream?', South African Journal of Childhood Education 11(1), a940. https://doi.org/10.4102/sajce.v11i1.940

Copyright: (C) 2021. The Authors. Licensee: AOSIS. This work is licensed under the Creative Commons Attribution License. 
sociologists of education that schools and classrooms enact inequality. In looking at the senior certificate results, she comments on the poor Matic percentage pass rates in districts and the declining grade averages in the schools. She records how most primary school teachers complain about the current school curriculum, and how they have almost no discretionary space in terms of pace and content coverage. She uses the vantage point of this specific place to show the compromised nature of the 1994 political settlement and the limited extent of redistribution in schooling and more broadly:

By now, there is a powerful accumulation of research showing that inequalities in schooling follow predictable patterns of social class, race, gender, region, and language. Research also shows the stubborn endurance of inequalities in the face of multiple attempts to shift them. (p. 3)

In the initial chapters, Christie relies on historical sources:

$[T]$ o show the impact of colonial expansion into the semiarid, sparsely peopled land in the 1800s and to show how patterns of possession and dispossession took racialised forms that hardened over time. (p. 14)

Christie found that social relations established in Carnarvon during colonial times persist today and have salience in the current ownership of land and economic resources, as well as in the town's institutions':

The struggle over the control of these institutions - in particular the schools - has been a central dynamic in the social relations of the town, exemplifying the intersectional relationships of lingering inequalities characteristic of coloniality. (p. 14)

In the second part of the book, Christie focuses on the post-apartheid period and examines the struggle over the schools in post-apartheid education restructuring. Once again context is used to illustrate the inadequacies of the political settement to address inequality in both schools and society.

The fieldwork research of this study combined the documents, systematic observations and formal interviews, with views and information that Christie gathered more informally from the people and the place. Christie explains that she was at pains "to leave an "audit trail" as a form of research accountability' and 'to provide a trustworthy account that contributes to scholarship'.
However, as an accomplished researcher, Christie admits that the project brought her great challenges:

I had anticipated that, armed with my research design and university ethical clearance, I would be able to investigate schooling arrangements, how these related to the comings and goings of daily life of the town, and what schooling offered for the future of young people living in this place. I had also hoped that it would be possible to throw some light on the links between the 'big science' of the SKA and improvements for local people, particularly in schooling. However, I had misread the complexity of what I was to find. (p. 11)

In the concluding chapter, Christie explores the possibilities of shifting the inequalities in schooling, drawing on the challenge of decoloniality theorists and others that the form of the conversation needs to be changed. She argues that South Africa's legacy of political and social activism around education provides a reservoir of experience for critical reflection and action in decolonising projects in schooling, alongside broader social, political and economic movements for change.

\section{According to Christie:}

There are no blueprints for a decolonial schooling system. What is required is to work beyond the inevitabilities of current inequalities towards a different imaginary and different aspirations for schooling, as well as for education beyond schooling. (p. 209)

Christie echoes the conclusions from her previous book and calls for an ethical stance of reciprocal, collective responsibility and repair. She also calls for the affirmation of human dignity and equal sharing in one world. She believes in the collective work of social and economic change, and calls for political commitment to bring about this change. She argues that 'beyond victimhood and guilt, beyond blame and recrimination, lie the possibilities of building the all-world that we share with others, human and more than human, and the earth itself'.

Bringing together her years of field experience and her deep knowledge of educational sociology in order to understand the complexities of school change in South Africa, Christie has written a seminal work that deals with decolonisation not just in theory but also in the context of a specific place. She demonstrates that the work of decolonisation is far more complex than anyone might think it is. 